\title{
Colleters in Rubiaceae from forest and savanna: the link between secretion and environment
}

\author{
Fernanda Tresmondi $^{1} \cdot$ Yve Canaveze $^{2} \cdot$ Elza Guimarães $^{2} \cdot$ Silvia Rodrigues Machado $^{2}$
}

Received: 19 December 2016 / Revised: 7 February 2017 / Accepted: 9 February 2017 /Published online: 1 March 2017

(C) Springer-Verlag Berlin Heidelberg 2017

\begin{abstract}
This study aims to investigate colleters' secretory function, on cellular level, in Rubiaceae species from contrasting environments looking to explore the association between secretion and environment. We collected samples from eight species of Rubiaceae growing in forest and savanna having standard-type colleters with diverse histochemistry (hydrophilic, lipophilic and mixed secretions) and processed for both conventional and cytochemical study under transmission electron microscopy (TEM). The standard colleters, although similar in morphology and anatomy, exhibited marked differences on cellular level, especially in the abundance and topology of Golgi bodies, endoplasmic reticulum and plastids when comparing forest and savanna species. These differences were clearly aligned with the chemical nature of the secretions they produce, with predominance of hydrophilic secretions in forest species and lipophilic or mixed secretions in savanna species. The combination of methods in electron microscopy revealed the sites of synthesis and intracellular compartmentation of substances, the mechanisms of their secretion from the protoplast and confirmed the involvement of the outer walls of the epithelial cells in the elimination of exudates to the gland surface. Our study
\end{abstract}

Communicated by: Sven Thatje

Silvia Rodrigues Machado

smachado@ibb.unes.br

1 Graduation Program in Biological Sciences (Botany), Institute of Biosciences (UNESP), São Paulo State University, Rua Prof. Dr. Antonio Celso Wagner Zanin, s/no, Caixa Postal 510, Botucatu, SP 18618-000, Brazil

2 Department of Botany, Institute of Biosciences (UNESP), São Paulo State University, Rua Prof. Dr. Antonio Celso Wagner Zanin, s/no, Caixa Postal 510, Botucatu, SP 18618-970, Brazil suggests a potential environment-associated plasticity of the secretory cells of standard-type colleters in modulating their secretory function performance.

Keywords Colleters $\cdot$ Cytochemistry $\cdot$ Functional plasticity · Rubiaceae $\cdot$ Secretion $\cdot$ Ultrastructure

\section{Introduction}

Plant secretion is a complex process involving various steps including the synthesis and breakdown of cellular components, the intracellular accumulations of substances, the interchange between organelles, the exit of substances from the protoplast and the elimination of substances out of the cell (Fahn 1979). Studies on secretory function in plants, including the knowledge of the chemical composition of exudates, and how that secretory activity on cellular level is influenced by climate factors, such as UV radiation (Kakani et al. 2003) and photoperiod, intensity of light and temperature can provide critical data for understanding the functional versatility of plant secretory cell responses to climatic changes (Roshchina and Roshchina 1993).

Among the specialised secretory structures which are located on the surface of the aboveground parts of the plant, thus in the limit zone plant environment, are the colleters. They are multicellular glands located near the base of stipules covering young shoots (see Thomas 1991) that produce a fluid secretion that is mucilaginous or resinous in nature. Functionally, these glands have been associated to a protective function against dehydration and lubrication of young organs and can act as physical and chemical barriers to pathogens and herbivores (Fahn 1979; Roshchina and Roshchina 1993; Evert 2006). 
The structural and histochemical organisation of colleters in different plant families has been frequently described (see Lacchia et al. 2016). However, in general, colleter biology remains poorly understood and studies addressing the attributes of colleter functioning and their association with the environment are scarce. Understanding how plants recognise and respond to environmental signals, at different levels of organisation, is critical and has become increasingly important in the climate-changing perspective (Nicotra et al. 2010).

Although some colleter characteristics (e.g. morphology, number and distribution) may be phylogenetically determined (Sheue et al. 2012, 2013), some studies have reported changes in colleters' functional performance traits associated with environment, which suggests that there is an ecological constraint related to the role of secretion in natural conditions (Sheue et al. 2012, 2013; Tresmondi et al. 2015). By comparing members of Rubiaceae growing in contrasting vegetation types (forest and savanna), we found that colleters similar in morphology and anatomical organisation differ in the chemical composition of secretions (Tresmondi et al. 2015). In Tresmondi et al. (2015), we found differences in the nature of secretion, luminosity and proportion of apex damage among Rubiaceae species growing in savanna and forest. We registered colleters with lipophilic secretions in savanna species, which grew in environments with higher luminosity and exhibited a lower proportion of damaged apices. In contrast, we observed a predominance of hydrophilic secretions in forest species, which grew in habitats with lower luminosity, and showed higher proportion of damaged apices. These observations suggest that in these species, colleters' functioning may be influenced by the environmental conditions, leading to a compositional change in the secretions.

Rubiaceae is the fourth largest angiosperm family, with a cosmopolitan distribution over a broad range of environments, predominantly in the tropics, where many species are endemic, ecologically sensitive to climate changes and therefore have restricted distributions (Davis et al. 2009). Although colleter's ultrastructure has been described for several Rubiaceae species (Klein et al. 2004; Miguel et al. 2006, 2010; Machado et al. 2012; Coelho et al. 2013), studies on cellular level comparing colleters of the same morphotype in distinct vegetation types may increase our knowledge on the influence of environment in the secretory process.

Here, to explore putative associations between environment and colleter secretory function, on cellular level, we combine methods in cytochemical and conventional electron microscopy. We investigate eight Rubiaceae species growing in forest and savanna including all three subfamilies (Cinchonoideae, Ixoroideae and Rubioideae) and seven genera (Coccocypselum, Guettarda, Palicourea, Psychotria, Simira, Tocoyena and Warzewiczia). We focus on epithelial cells, and we explored, in a comparative way: (1) differences in the organelle populations among colleters from species occurring in forest and savanna, (2) the sites of intracellular compartmentation of materials, (3) the mechanisms of their secretion from the protoplast and (4) the architecture of the outer cell walls and cuticle, questioning the possible involvement of these compartments in the elimination of exudates to the gland surface.

\section{Materials and methods}

\section{Plant material, site of study and sampling}

We selected eight Rubiaceae species (Table 1) from tropical seasonal semideciduous forests and savanna fragments located in central-western São Paulo state, Brazil $\left(48^{\circ} 20^{\prime}\right.$ to $48^{\circ}$ $50^{\prime} \mathrm{W} ; 22^{\circ} 40^{\prime}$ to $23^{\circ} 05^{\prime} \mathrm{S}$ ), having standard-type colleters with hydrophilic, lipophilic and mixed secretions (Tresmondi et al. 2015). All of these species' standard-type colleters comprise a central axis of parenchyma cells sheathed by an outer palisade-like epidermis (secretory epithelium), and the colleters as a whole, are covered by a cuticle layer (Tresmondi et al. 2015).

Savanna and seasonal semideciduous forest are both characterised by seasonal climate, characterised as Cfa hot climate with summer rains and slightly dry winter, with the average temperature in the hottest month above $22{ }^{\circ} \mathrm{C}$, with small hydric deficiency in April, July and August (Cunha and Martins 2009). The savanna area (720 m average altitude), locally called 'cerrado', is characterised by an annual average temperature of $21^{\circ} \mathrm{C}$ and an annual average rainfall of $1128 \mathrm{~mm}$ (Déstro and Campos 2006). The soils are classified as Latosol and Argisol (according to the Brazilian System of Soil Classification, Empresa Brasileira de Pesquisa Agropecuária (EMBRAPA) 1999) that are dystrophic, acidic soils, which have extremely low nutrient availability and high levels of soluble aluminium (Al) (Coutinho 2002). The forest area, with $500 \mathrm{~m}$ average altitude, is characterised by an annual average temperature of $19.4{ }^{\circ} \mathrm{C}$ and an annual average rainfall of $1300 \mathrm{~mm}$. The soils are classified as nitisol (Carvalho et al. 1991) that is a deep, red, well-drained soil with a clay content of more than 30\% (Delvaux and Brahy 2014).

For every species, we monthly monitored five plants to determine the specific sprouting period. We investigated the presence and aspect of exudates covering the shoot apices by the naked eye. Then, we collected shoot apices, from five individuals of each species, containing stipules with colleters active in secretion (characterised by a swollen aspect, yellowish colour and the presence of a hyaline exudate on the surface). We immediately fixed the samples for both conventional and cytochemical study under transmission electron microscope (TEM). 
Table 1 Types of secretion present in the standard colleters of eight Rubiaceae species from forest and savanna vegetation in central-western São Paulo State, Brazil

\begin{tabular}{lll}
\hline Type of secretion & Plant species & Vegetation type \\
\hline Hydrophilic & Psychotria hoffmannseggiana (Willd. ex Schult.) Müll. Arg. & Forest \\
& Simira corumbensis (Standl.) Steyerm. & Forest \\
& Warzewiczia sp. & Forest \\
Mixed & Coccocypselum lanceolatum (Ruiz \& Pav.) Pers. & Savanna \\
& Tocoyena formosa (Cham. \& Schltdl.) K. Schum. & Savanna \\
Lipophilic & Guettarda viburnoides Cham. \& Schltdl. & Savanna \\
& Palicourea rigida Kunth. & Savanna \\
& Palicourea sp. & Savanna \\
\hline
\end{tabular}

We deposited voucher specimens in Herbarium BOTU from the Department of Botany, Universidade Estadual Paulista (Unesp), Botucatu, São Paulo state, Brazil.

\section{Ultrastructural studies}

For conventional analysis in TEM, we fixed the samples in glutaraldehyde (2.5\% with $0.1 \mathrm{M}$ phosphate buffer, $\mathrm{pH} 7.3$, for $6-8 \mathrm{~h}$ at $4{ }^{\circ} \mathrm{C}$ ) and post-fixed with $1 \%$ osmium tetroxide $\left(\mathrm{O}_{\mathrm{s}} \mathrm{O}_{4}\right)$ aqueous solution in the same buffer for $2 \mathrm{~h}$ at room temperature. Then, we dehydrated the samples using a graded acetone series and embedded in Araldite resin at room temperature. We carried out the polymerisation at $60^{\circ}$ for $48 \mathrm{~h}$. Later, we stained ultra-thin sections with uranyl acetate and lead citrate (Reynolds 1963) and examined with a TEM Tecnai Spirit (FEI) at $60 \mathrm{kV}$.

We employed ultracytochemical methods in TEM for labelling cellular components: the Thiéry (1967) method for polysaccharides using the periodic acid-thiosemicarbazidesilver proteinate (PATAg) test, the ammoniacal silver method for basic proteins (MacRae and Meetz 1970), the osmiumimidazole technique for unsaturated lipids (Angermüller and Fahimi 1982) and the zinc iodide-osmium tetroxide (ZIO) method for endomembrane impregnation (Reinecke and Walther 1978). We examined the samples using a FEI Tecnai Spirit TEM at $80 \mathrm{kV}$. We generated the controls for each method according to the specific protocols for each test.

\section{Results}

We investigated the subcellular organisation, cytochemistry and secretion mechanisms of stipular colleters in the eight species of Rubiaceae from savanna and forest. We focused our analyses on the epithelial cells because they are directly involved in the synthesis, transport and elimination of the exudates. We grouped the results based on the predominant chemicals in the exudates (hydrophilic, lipophilic and mixed secretions).

\section{Hydrophilic secretions}

The epithelial cells of standard-type colleters producing hydrophilic secretions (Psychotria hoffmannseggiana, Simira corumbensis and Warzewiczia sp.) were characterised by an electron-dense outer tangential wall covered with irregularly thickened cuticle, a large nucleus, abundant cytoplasm and undeveloped vacuole (Fig. 1a). The nucleus exhibited a lobed contour and a single, compact nucleolus (Fig. 1b). The cytoplasm was rich in free ribosomes, polyribosomes, mitochondria, hyperactive Golgi bodies, rough endoplasmic reticulum elements (RER) and modified plastids (Fig. 1a-d). Mitochondria were elongated, had a dense matrix and dilated cristae (Fig. 1b, d) and were grouped around the nucleus (Fig. 1b) or dispersed throughout the cytoplasm (Fig. 1d). Plastids were ovoid (Fig. 1b) or amoeboid (Fig. 1c), devoid of thylakoids and exhibited dense stroma and crystalloid bodies identified as proteins. The Golgi bodies were numerous and well-developed and had six to ten stacked cisternae with easily identifiable cis, median and trans-faces, in conventional preparations (Fig. 1d, e). We observed vesicles containing fibrillar or granular dense material emerging from the ends of the cisternae from the cis-face towards the trans-Golginetwork region (Fig. 1d, e). We clearly identified the proximity of the Golgi body cisternae with the rough endoplasmic reticulum elements (Fig. 1d, e). In these cells, we could also observe the coalescence of Golgi body-derived secretory vesicles (Fig. 1f) and images suggestive of vesicle fusion with the vacuolar membrane or, incorporation of the vesicle content to the vacuole (Fig. 1g). There were elements of the endoplasmic reticulum dispersed throughout the cytoplasm or in clusters close to Golgi bodies (Fig. 1d, e) and near the plasma membrane (Fig. 2a, c, f). In these cells, images suggested there was a fusion of the vesicles with the plasma membrane (Fig. 2a, b, $\mathrm{e}, \mathrm{f}$ ), a process that resulted in a sinuous outline of the plasma membrane (Fig. 2a, b, e). There were accumulations of fibrillar or granular material, identified as polysaccharides, in the periplasmic space (Fig. 2a, b). Additionally, we observed multivesicular bodies (MV) near the plasma or vacuolar membrane, and images suggested there was an incorporation of MV into the vacuole (Fig. 2c). 
Fig. 1 Epithelial cells of colleters of Simira corumbensis (a-d, f), Psychotria hoffmannseggiana (e) and Warzewiczia sp. (g). a General view showing the electron-dense outer tangential cell wall and the irregularly thickened cuticle. Note the presence of intercellular spaces (is) and small vacuoles $(v a)$. b Nucleus $(n u)$ with lobed contour and compact nucleolus $(n c)$. Note the elongated mitochondria $(\mathrm{mi})$ and ovoid plastids $(p l)$ near the nucleus. c Polymorphic plastid $(p l)$ containing dense protein inclusions (asterisk). d Cytoplasm showing free ribosomes, polyribosomes, elongated mitochondria $(\mathrm{mi})$, Golgi bodies $(G b)$ with associated vesicles and rough endoplasmic reticulum (rer). e Golgi body close to rough endoplasmic reticulum (rer) elements. f Vesicles from Golgi bodies containing granular material. Note signs of vesicle fusion (arrow). g Vesicles filled with granular contents close to, or fused to, the vacuolar membrane (white arrows). Note hyperactive Golgi bodies $(G b)$
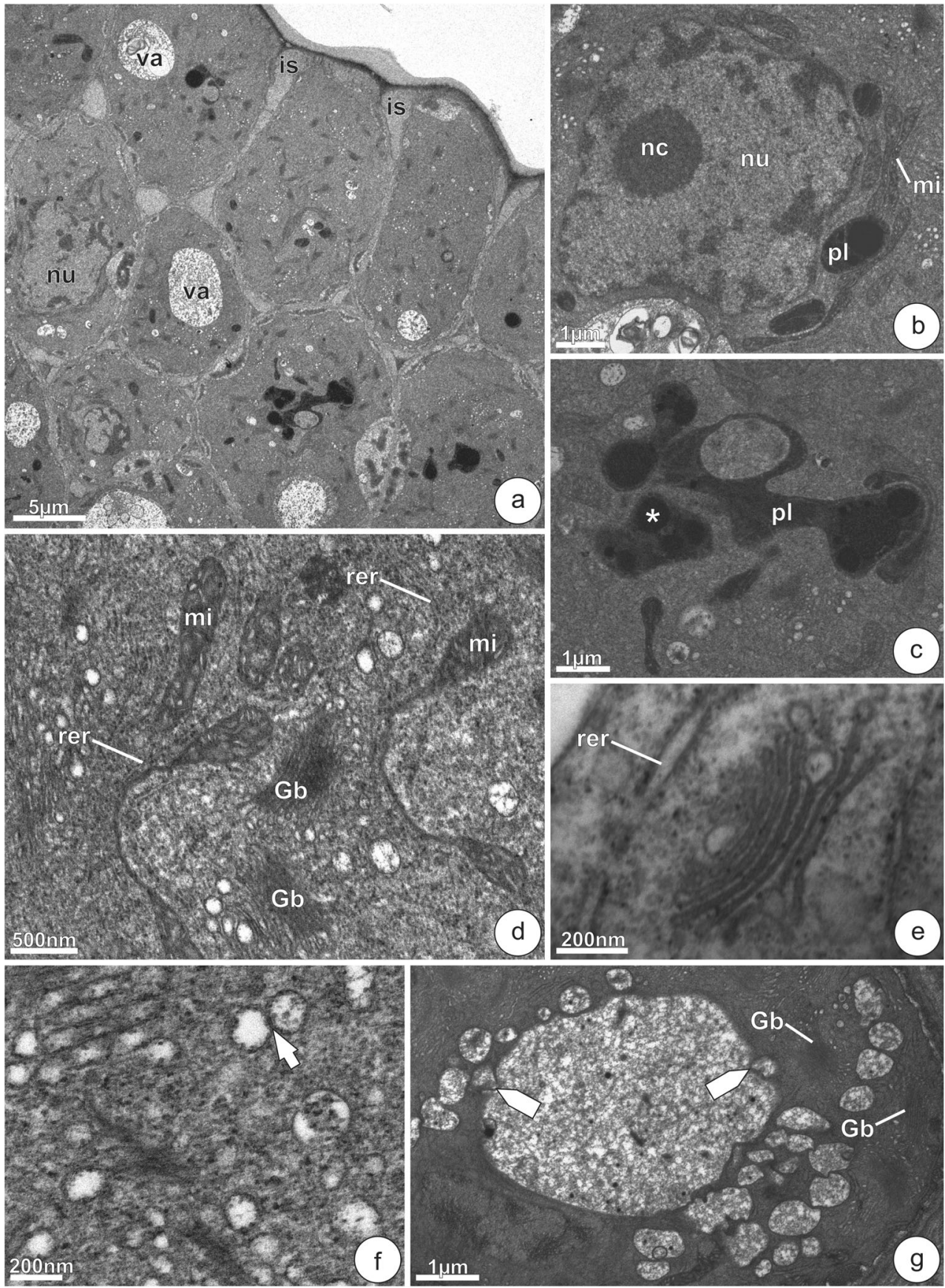

During the secretory process, the cell walls of the epithelial cells underwent significant changes (Fig. 2a, d-f). The first signs of cell wall change were the swelling of the middle lamella and the separation of the anticlinal walls in disjoint regions of the epithelial cells (Fig. 2a), forming intercellular spaces where the secretions accumulated. Gradually, these intercellular spaces coalesced and occupied the entire extension of the cell, reaching the outer tangential wall (Figs. 1a and $2 \mathrm{~d}, \mathrm{e})$. This process was accompanied by a remarkable change in the architecture of the outer tangential wall. In
S. corumbensis, the basal layer (innermost and adjacent to the plasma membrane, also thinner and amorphous) and the median layer (thicker and electron-dense) were separated from one another forming a broad space which became filled with exudate (Figs.1a and 2d). In Warzewiczia sp., the basal and median layers became loose and seemed to flake off (Fig. 2e, f). In this species, cell wall dissolution can reach the cuticular layer resulting in the disruption of the network formed by polysaccharide wall projections (Fig. 2f). In all samples, the cuticle proper (seen here as a thinner, 

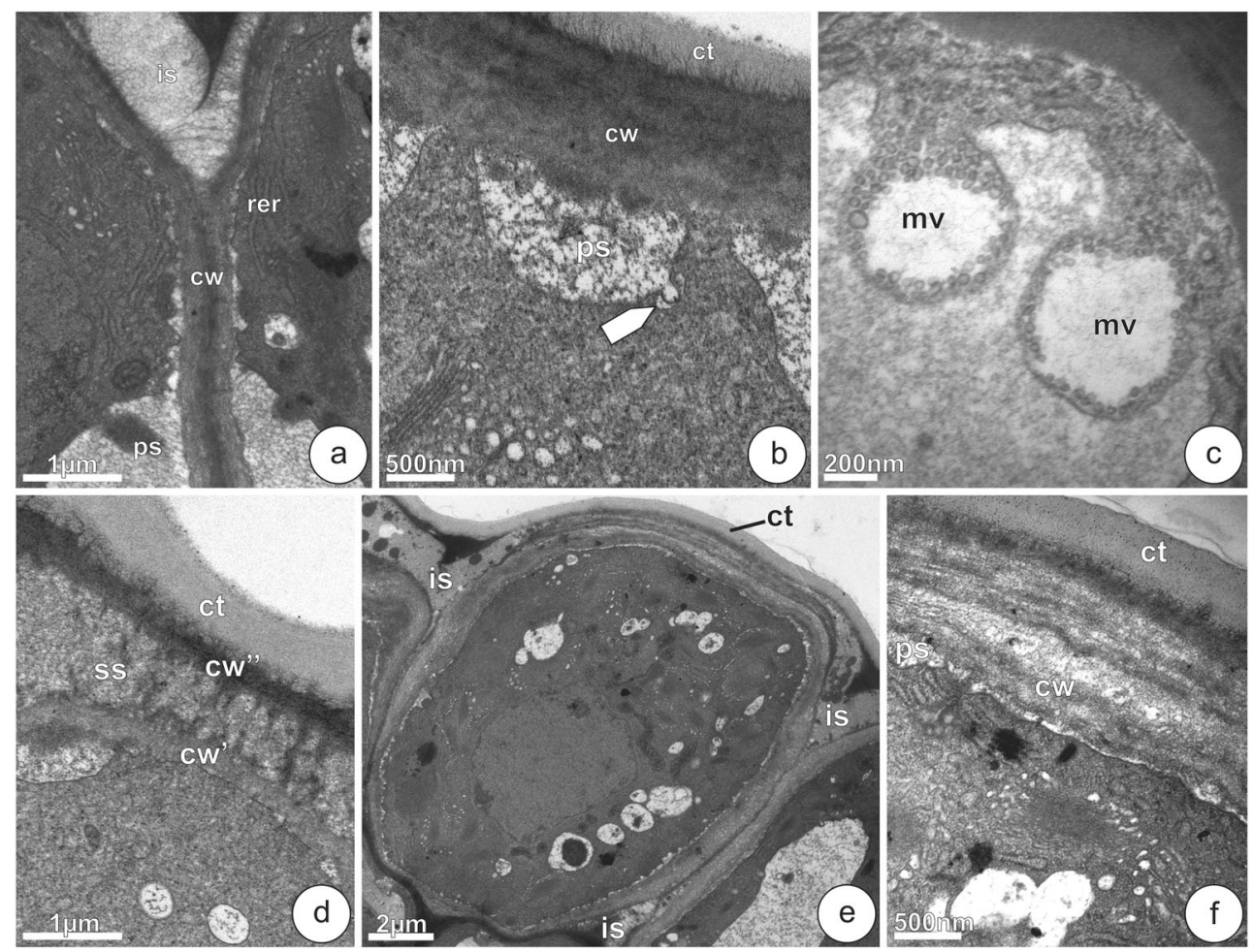

Fig. 2 Epithelial cells of colleters of Warzewiczia sp. (a, c, h) and Simira corumbensis $(\mathbf{b}, \mathbf{e})$. a Rough endoplasmic reticulum (rer) elements juxtaposed to the plasma membrane that exhibit a sinuous outline. Note periplasmic space $(p s)$ with accumulated fibrillar material and intercellular space (is) formed by dissolution of the middle lamellae along the anticlinal wall $(\mathrm{cw})$. b Fusion of vesicle (white arrow) with the plasma membrane. Note fibrillar material inside the periplasmic space $(p s)$, and thick outer tangential cell wall $(\mathrm{cw})$ showing dense fibrillar projections inside the cuticular layer $(c t)$. c Multivesicular bodies $(m v)$ associated with the vacuolar membrane. Note rough endoplasmic reticulum in the peripheral cytoplasm. d Signs of disintegration of the outer tangential cell wall. Note the separation of the basal $\left(c w^{\prime}\right)$ and intermediate ( $\left.c w^{\prime \prime}\right)$ cell wall layers forming a site of accumulation of the secretions $(s s)$. The intact cuticle $(c t)$ is attached to the cell wall. e General view of the epithelial cell showing intercellular spaces $(i s)$ originated by the dissolution of the middle lamellae and sites of secretion accumulation resulting from the disintegration of the outer tangential wall. Note the intact cuticle $(c t)$. f. Detail of the outer tangential cell wall $(\mathrm{cw})$ with a very loose structure followed by the periplasmic space $(p s)$ and peripheral cytoplasm rich in polyribosomes, hyperactive Golgi bodies and rough endoplasmic reticulum elements close to, or fused to, the plasma membrane. Note intact cuticle $(c t)$ amorphous layer devoid of polysaccharide projections) remained intact (Figs. 1a, 2b, d-f and 3e, f).

The ZIO solution penetrated membranes and contents of the cisternae of the Golgi bodies and surrounding vesicles (Fig. 3a-c). In some Golgi bodies, only trans-cisternae with vesicles in their enlarged ends were marked by ZIO (Fig. 3c), which could indicate differential activity between the cisternae. The Thiéry method marked the polysaccharides, seen as very small electron-dense granules inside the cisternae of Golgi bodies and secretory vesicles (Fig. 3g), and clearly showed the cell compartments that were associated with the accumulations of hydrophilic secretions: inside regions formed by the dissolution of the middle lamella along the anticlinal walls (Fig. 3d), in the periplasmic space (Fig. 3e, g), inside the outer tangential walls (Fig. 3e, f) and in the vacuoles (Fig. $3 \mathrm{~g}$ ). This method also detected polysaccharide granulations through the cuticle and retained on the outer surface of the gland (Fig. 3f), confirming the permeability of the cuticle to the mucilaginous fluid.

\section{Lipophilic secretions}

The epithelial cells of standard colleters producing lipophilic secretions (in Palicourea sp., Palicourea rigida and Guettarda viburnoides) exhibited voluminous, spherical nuclei, dense cytoplasm with modified plastids and electrontranslucent vacuoles with irregular outline (Fig. 4a). Plastids varied in size and shape and were devoid of membranessome contained prominent dense bodies (Fig. 4b, c) or dense granulations together with small starch grains that exhibited signs of degradation (Fig. 4a). Elements of smooth endoplasmic reticulum (SER), just visible in conventional preparations, were clearly abundant in the ZIO preparations (Fig. 4d, e). The SER elements exhibited dilated extremities with associated vesicles which were filled with dense contents (Fig. 4d). The SER profiles were numerous, mainly in the peripheral cytoplasm (Fig. 4d) and close to plasma membrane and, or, plasmodesmata (Fig. 4e).

The lipophilic material, seen as electron-opaque inclusions in cytoplasm and inside the wide intercellular spaces 

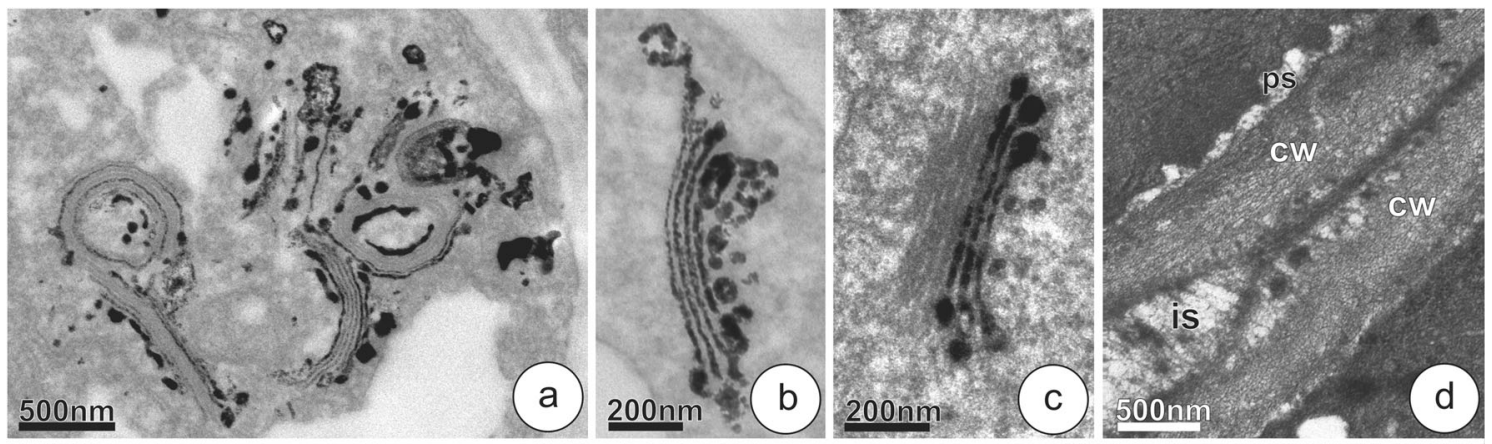
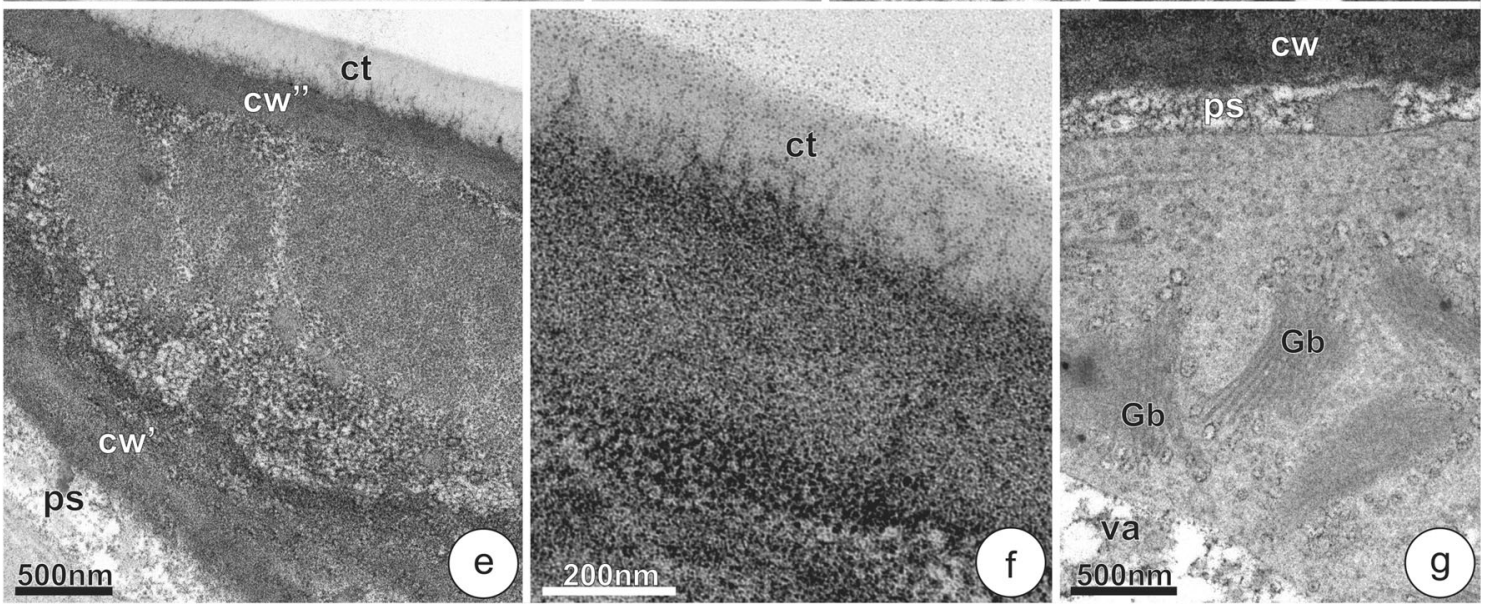

Fig. 3 Epithelial cells of Psychotria hoffmannseggiana (a), Warzewiczia sp. (b-d) and Simira corumbensis (e-g) colleters. a Golgi body cisternae, rough endoplasmic reticulum membranes and vesicles marked by ZIO solution. b All cisternae and vesicles from Golgi body marked by the ZIO method. c Only trans-cisternae of Golgi body marked by the ZIO method. d Polysaccharides marked by the Thiéry method are seen as a dense material inside the periplasmic spaces $(p s)$, intercellular space $(i s)$ and cell walls $(\mathrm{cw})$. e Polysaccharides marked by the Thiéry method in the

(Fig. 4a) that resulted from cell-wall dissolution (Fig. 4c), showed a differential reaction with the tetroxide osmiumimidazole method: some materials were strongly marked with this solution (Figs. 4c and 5a), while others remained electron-lucent and did not reacted with the solution (Fig. 5a). It was noticeable that dense lipophilic material was restricted to the protoplast of epithelial cells (Figs. 4c and 5a), while electron-lucent material occurred in both protoplast and intercellular spaces (Fig. 5a), where it was more abundant.

The outer tangential cell wall was strongly electron dense (Figs. 4a and 5b) and exhibited uneven thickness and lipid incrustations in the cuticular layer (Fig. 5b). The polysaccharide stratum protruded inside the cuticular layer forming a network of electron-dense bands (Fig. 5b, c). After the changes in the outer tangential cell wall, the value of the Thiéry method became evident, as it displayed the loose lamellar structure of the inner wall layers and the small pockets in the median layer (Fig. 5c). The thick cuticle remained intact. periplasmic space ( $p s)$, inside the broad space originating by separation, or disintegration, of the basal $\left(c w^{\prime}\right)$ and intermediate ( $\left.c w^{\prime}\right)$ cell wall layers. Note the intact cuticle $(c t)$. f Note the granular material (polysaccharides) marked by the Thièry method embedded in and on the cuticle $(c t)$. g Golgi body cisternae $(G b)$ and vesicles marked by the Thiéry method. Note polysaccharides in the vacuole $(v a)$ and periplasmic space $(p s)$ subjacent to the outer tangential cell wall $(c w)$

\section{Mixed secretions}

The epithelial cells of standard colleters producing mixed secretions (in Coccocypselum lanceolatum and Tocoyena formosa) presented abundant cytoplasm rich in free ribosomes, polyribosomes, extensive RER, abundant smooth endoplasmic reticulum (SER), well-developed Golgi bodies, modified plastids and elongated mitochondria (Fig. 6a-d). Vacuoles were small, spherical and contained membrane debris and granular material identified as polysaccharides (Fig. 6c). The Golgi bodies had 10 to 12 cisternae with enlarged ends where vesicles sprouted (Fig. 6b, c). Plastids were globular or polymorphic, devoid of thylakoids and may have contained starch grains together with dense inclusions (Fig. 6a) or only lipophilic inclusions with different electron densities (Fig. 6b, c). We observed prominent periplasmic spaces containing polysaccharides along the anticlinal walls (Fig. 6c). The anticlinal walls of the epithelial cells had a loose appearance (Fig. 6c) and extensive intercellular channels were formed after the dissolution of the middle lamella (Fig. 6d). 


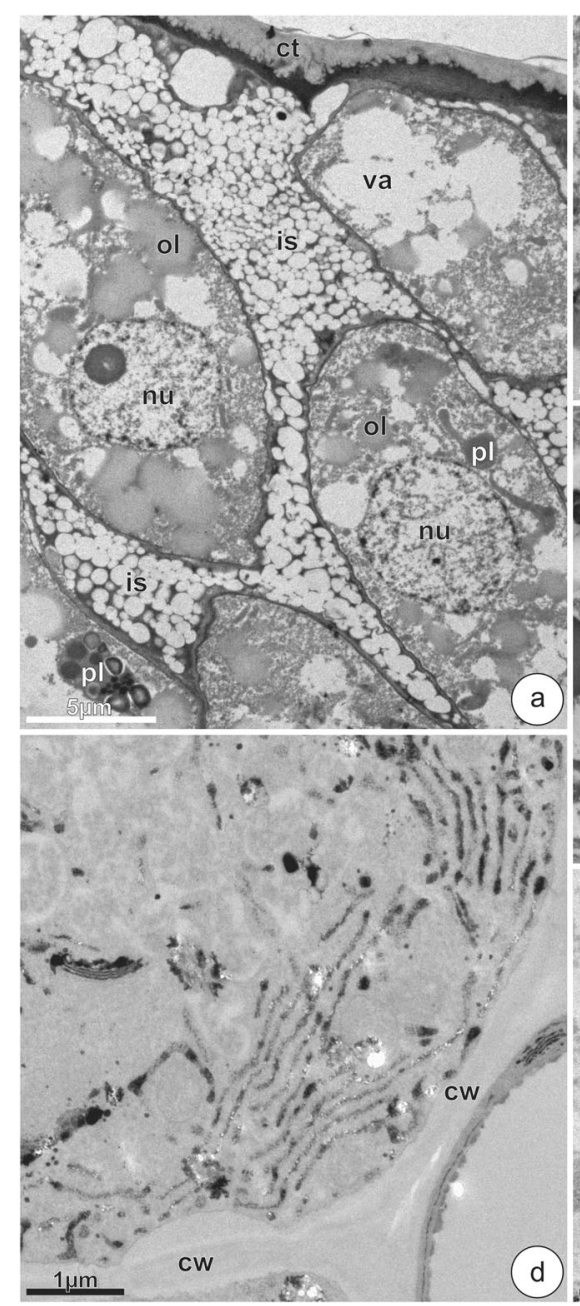

Fig. 4 Epithelial cells of colleters of Palicourea rigida $(\mathbf{a}-\mathbf{c})$ and Palicourea sp. (d, e). a Epithelial cell with spherical nucleus $(n u)$, plastids $(p l)$ and vacuoles $(v a)$ filled with oil bodies $(o l)$. Note the extensive intercellular space (is) filled with lipophilic secretion and the very electron-dense outer tangential cell wall covered with a thick cuticle $(c t)$. Note the plastid $(p l)$ containing starch grains in the inferior left corner. b Polymorphic plastid $(p l)$ with homogenous stroma and dense inclusions close to the nucleus $(n u)$. c Signs of disintegration of the

Also, we observed dense bodies strongly stained with tetroxide of osmium-imidazole inside the plastids (Fig. 6c), scattered in the cytoplasm and in the intercellular spaces mixed with polysaccharides (Fig. 6d) and in the periplasmic space (Fig. 7a). Lastly, the ZIO solution marked the membranes and contents of SER and showed SER profiles arranged perpendicular to the plasma membrane (Fig. 6e), vesicles and the trans-cisternae of Golgi bodies (Fig. 6e, f).

The outer tangential walls of the epithelial cells presented three distinct layers: a somewhat loose inner layer with a spongy aspect, which was adjacent to the plasma membrane; a fibrous electron-dense median layer, and a thick cuticle with two distinct regions: the cuticular layer, which was thick and characterised by an electron-dense fibrillar network, and the true cuticle that was thinner and amorphous (Fig. 7a). The

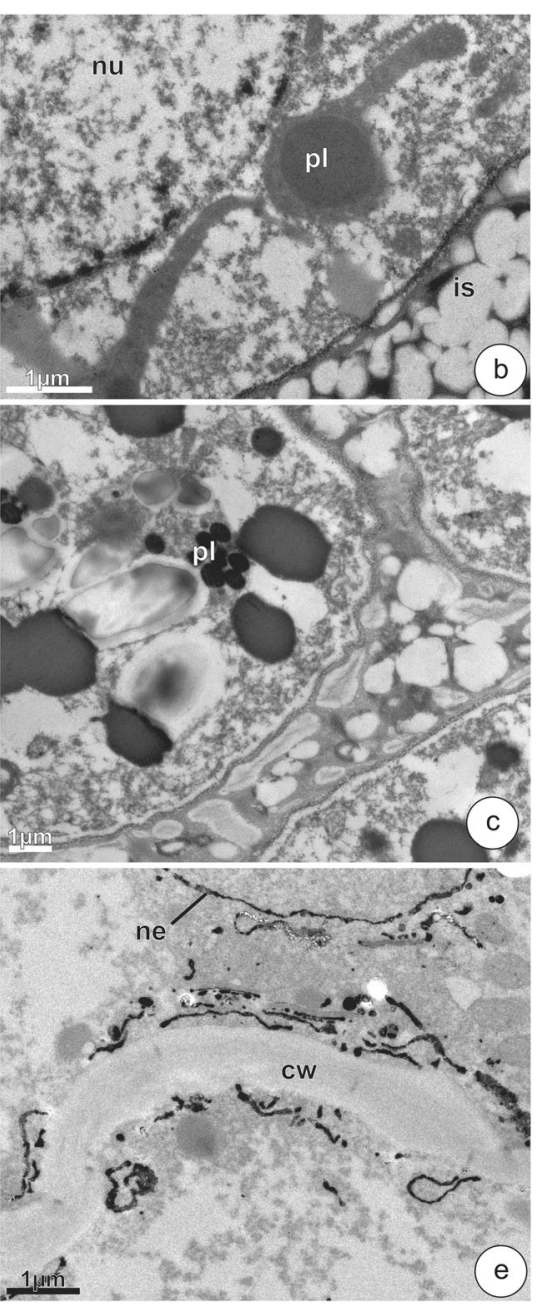

anticlinal walls of the epithelial cells. Note the electron-dense bodies inside the plastids $(p l)$ marked by the tetroxide osmium-imidazole solution. d Smooth endoplasmic reticulum elements marked by the ZIO method, close to the cell wall $(c w)$. Note some SER elements with enlarged ends, filled with dense contents. e Smooth endoplasmic reticulum elements, isolated or anastomosing, in the peripheral cytoplasm close to the cell wall $(\mathrm{cw})$ and adjacent to the nuclear envelope (ne)

increase in disorganisation of the polysaccharide layers reaching the cuticular layer and providing the appearance of gaps, was a characteristic sign of cell-wall changes associate with the secretion passage (Fig. 7b, c). Also, we detected accumulations of lipids in the gaps, while polysaccharides (viewed as granular materials) were abundant through the cell wall and cuticle (Fig. 7c).

\section{Discussion}

In this study, we examined the ultrastructure and cytochemistry of standard-type colleters from Rubiaceae species growing in distinct vegetation types and having different 


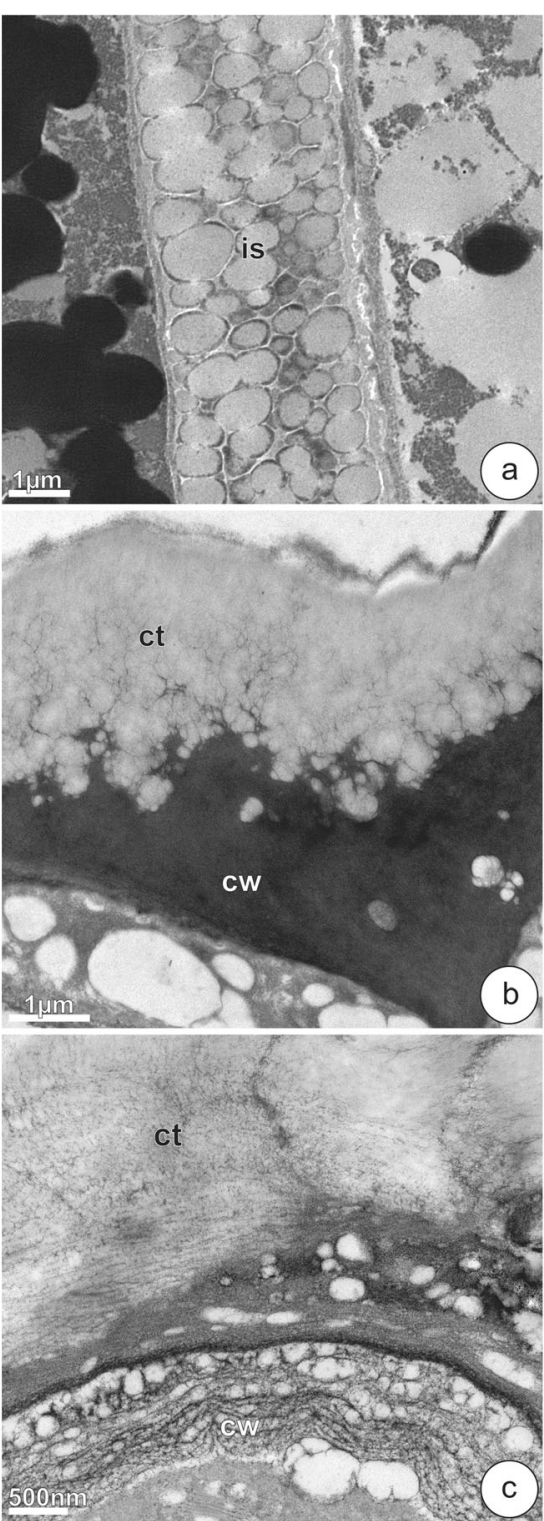

Fig. 5 Epithelial cells of colleters of Palicourea rigida $(\mathbf{a}, \mathbf{b})$ and Guettarda viburnoides (c). a Dense inclusions inside the protoplast marked by the tetroxide osmium-imidazole solution. Note the electrontranslucent inclusions in the cytoplasm and inside the intercellular space (is), not reactive to the treatment with osmium tetroxide-imidazole. b Compact and dense outer tangential cell wall $(\mathrm{cw})$ with incrustation of lipids reaching the cuticle $(c t)$. Note the thin dense ramification network in the cuticular layer. c Outer tangential cell wall treated by the Thiéry method. Note the loose structure of the inner cell wall layer ( $\left.c w^{\prime}\right)$, gaps in the intermediate layer ( $\left.c w^{\prime \prime}\right)$ and polysaccharide bands in the cuticular layer $(c t)$

histochemistries, looking to explore the association between secretion and environment.

We found that the general subcellular organisation of the epithelial cells of standard colleters is broadly similar to that reported by other studies and for other Rubiaceae (Klein et al. 2004; Miguel et al. 2010; Machado et al. 2012; Coelho et al. 2013). However, this study showed that standard colleters, which are similar in morphology and anatomical organisation, had significant differentiation and functioning on cellular level when comparing species from forest and savanna; e.g. we recognised differences in the abundance and topology of some organelles, manly Golgi bodies, endoplasmic reticulum and plastids. Although, cellular changes are common during the secretory cycle (see Fahn 2000), it is important to note that in this study all analysed colleters are at peak of secretion. Thus, we suggest that these differences are linked to the chemical nature of the exudates produced by colleters, which differed according to the vegetation type in which each species grows. Colleters from forest species that produced hydrophilic secretions were characterised by abundant and well-developed Golgi bodies with dilated cisternae giving the secretory vesicles, voluminous mitochondria, extensive rough endoplasmic reticulum and plastids containing protein inclusions. This subcellular organisation is common to mucilage glands of various species and is consistent with the synthesis and transport of protein/carbohydrate-based mucilage (Horner and Lersten 1968; Fahn 1979, 2000; Evert 2006). The coalescence of numerous smooth secretory vesicles derived from Golgi forming storage vacuoles is noticeable in these epithelial cells. In contrast, colleters from savanna species that produced lipophilic secretions were characterised by numerous amoeboid leucoplasts, well-developed mitochondria and abundant smooth endoplasmic reticulum (SER) in addition to the presence of copious amounts of lipophilic bodies. This ultrastructural organisation is typical of monoterpenes and resin glands (Fahn 2000; Turner et al. 1999; Turner and Croteau 2004; SáHaiad et al. 2015; Possobom et al. 2015). In addition, the appearance or proliferation of SER is closely related to the secretion of flavonoid aglycones (Wiermann 1981). Some Rubiaceae species from savanna, producing both lipophilic and hydrophilic secretions, exhibited organisation consistent with the ultrastructure of mixed glands (Fahn 1979; Evert 2006), as abundance of scattered SER, in addition to RER, well-developed Golgi bodies and modified plastids.

In all the studied colleters, independently of the nature of their secretion, the materials exited the protoplast before accumulating in the periplasmic spaces. Later, the exudates, of both hydrophilic and lipophilic components of the secretion, passed through the cell wall and were discharged into the intercellular spaces and, finally onto the gland surface. Our results show that the pathway of secretion release from the protoplast epithelial cells involves two distinct mechanisms both granulocrine and ecrine processes sensu Fahn (1979). The profusion of Golgi secretory vesicles and multivesicular bodies near the plasma membrane, or fusing with it, suggests that some components of the hydrophilic secretion exited the cells by exocytosis (Kronestedt-Robards and Robards 1991) and accumulated firstly in the periplasmic space, characterising the granulocrine process of secretion (Fahn 1979). In addition, images of ER elements in close proximity to the plasma membrane support the possibility that the 
Fig. 6 Epithelial cells of colleters of Tocoyena formosa $(\mathbf{a}, \mathbf{b}, \mathbf{d}-\mathbf{f})$ and Coccocypselum lanceolatum (c). a Detail of cytoplasm of an epithelial cell with rough endoplasmic reticulum (rer), plastids $(p l)$ and Golgi bodies $(G b)$. Note starch grains together with osmiophilic inclusions in the plastid $(p l)$. b Detail of polymorphic plastids $(p l)$ containing small lipid inclusions, hyperactive Golgi bodies $(G b)$ and mitochondria $(m i)$. $\mathbf{c}$ Round plastids $(p l)$ with prominent inclusions with variable electron densities and developed Golgi body $(G b)$. Note vacuoles $(v a)$ with membrane debris and polysaccharides. Along the anticlinal walls $(c w)$, note the periplasmic space $(p s)$ filled with polysaccharides. d Elongated mitochondria and osmiophilic bodies $(o l)$ in the cytoplasm of an epithelial cell. Note osmiophilic granules mixed with polysaccharides in the intercellular space (is). e Smooth endoplasmic reticulum elements, marked by the ZIO method, arranged perpendicularly to the plasma membrane adjacent to the outer tangential cell wall $(\mathrm{cw})$. $\mathbf{f}$ Detail of Golgi bodies marked by the ZIO method. Note positive reaction in the Golgi trans face
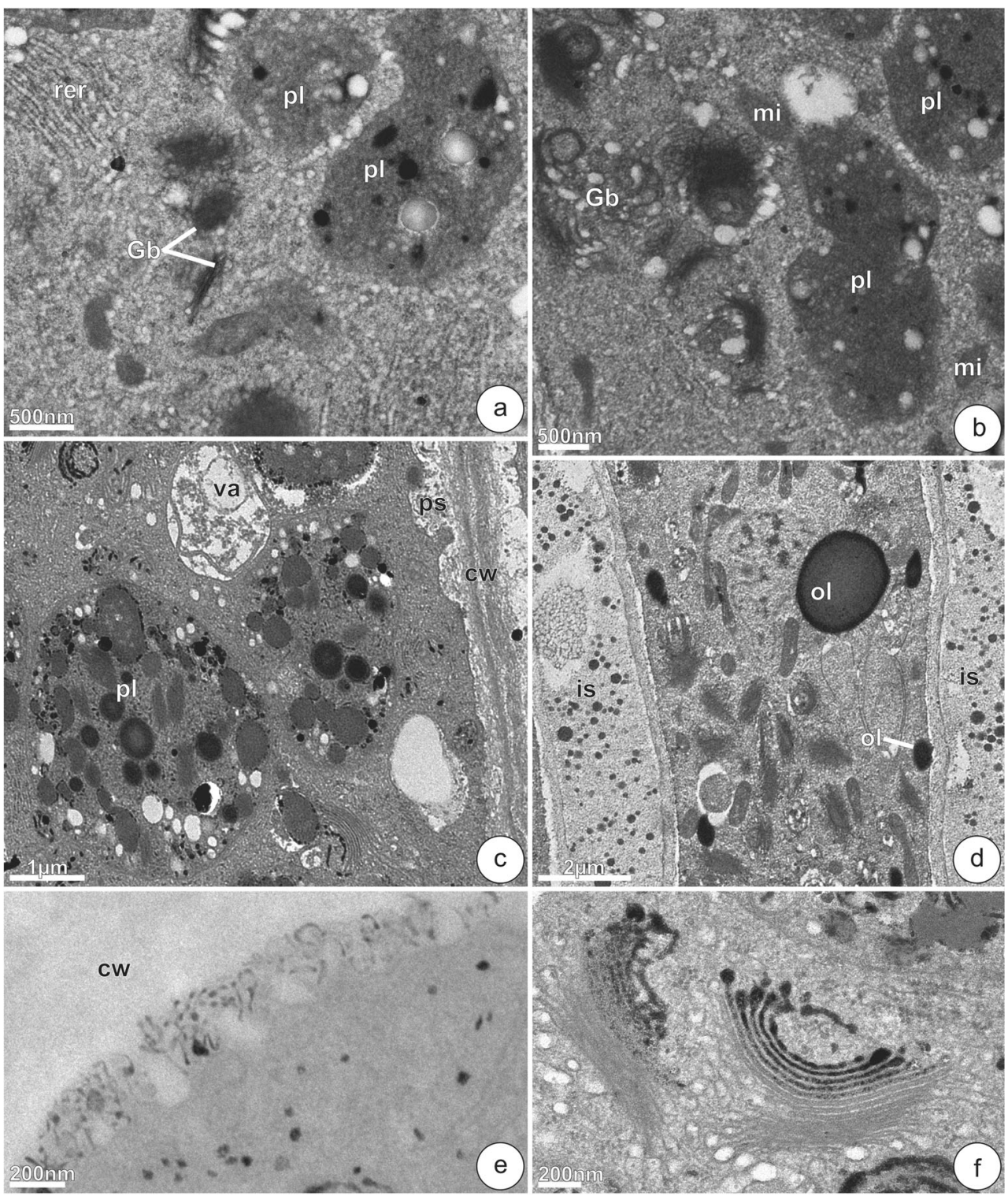

tubular ER participates in the release of lipophilic secretions to the outside of the protoplast by a transient fusion of their membranes with the plasmalemma (Benayoun and Fahn 1979; Vassilyev 2000) or the establishment of the permeable contacts between these membranes (Vassilyev 2000). Moreover, key components of the lipophilic secretions, oil droplets and resin, are able to cross the plasma membrane or tonoplast directly as a result of a concentration gradient or by an active processes, indicating the ecrine mechanism of secretion (Fahn 1979). These mechanisms involve intense metabolic activity of the secretory cells and are compatible with the presence of numerous mitochondria with well-developed cristae (Lüttge 1971; Roshchina and Roshchina 1993).

Changes in the walls of epithelial cells, such as dissolution of the middle lamellae of the anticlinal walls and the loosening of the polysaccharide layers, creating gaps, followed by the partial disintegration of the outer tangential walls, contribute to secretion release. Unlike other studies of colleters (Appezzato-da-Glória and Estelita 2000; Klein et al. 2004; Miguel et al. 2010), these cell wall changes occurred during the secretory stage and do not characterise a senescence stage. Cell wall changes are usually mediated by enzymatic processes, and the presence of polyribosomes, endoplasmic reticulum and secretory vesicles could be associated with the synthesis and transport of enzymes that participate in cell wall degradation (Hall et al. 1981).

In this study, we did not observe the formation of a typical subcuticular storage space formed by cuticle detachment. In all the inspected colleters, the secretion remained trapped in the gaps and/or immersed in the very loose wall layers of the outer tangential walls. The uninterrupted cuticle remains attached to the residual wall layer. We note that the discharge of 


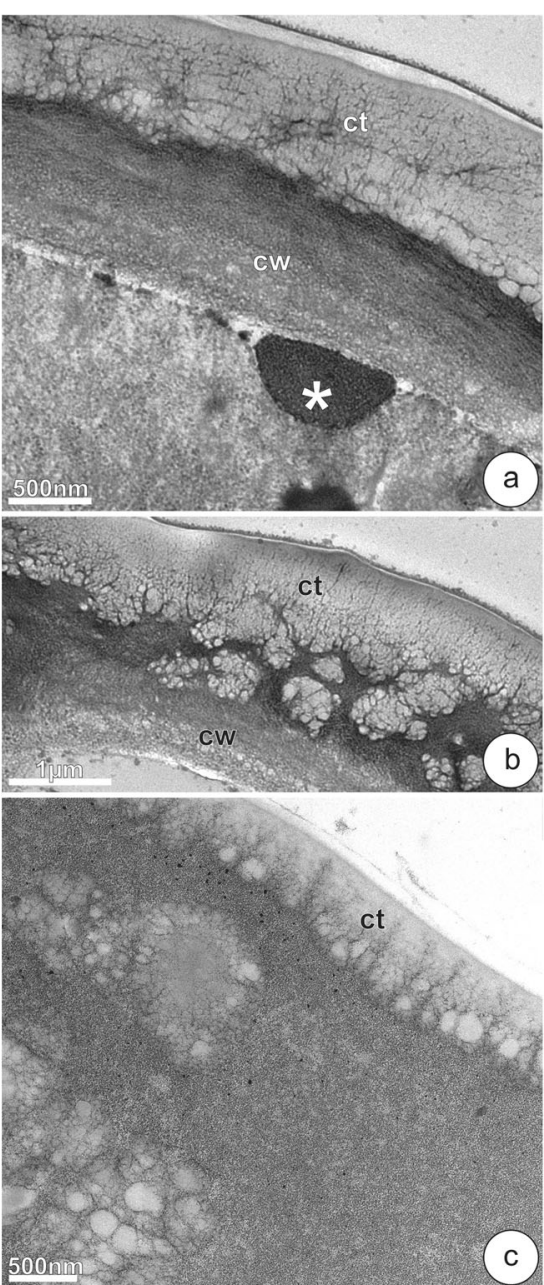

Fig. 7 Epithelial cells of colleters of Tocoyena formosa $(\mathbf{a}, \mathbf{b})$ and Coccocypselum lanceolatum (c). a Detail of the outer tangential cell wall $(c w)$ exhibiting pores in its inner layers and thick cuticle $(c t)$. Note electron-dense network of fibrillar material in the cuticular layer $(c t)$ and accumulation of lipophilic material in the periplasmic space (asterisk). b Detail showing increase in the porosity of the inner wall layers $(\mathrm{cw})$ and lipid incrustation reaching the cuticle $(c t)$. $\mathbf{c}$ Note lipid accumulations in the pores of the cell wall and cuticle, and polysaccharide granulations, marked by the Thiéry method, through the outer tangential cell wall and cuticle $(c t)$

abundant exudate onto the colleter surface occurred through the cuticle. The absence of pores in the cuticles of the colleters epithelial cell was also reported for the other Rubiaceae species (Klein et al. 2004; Miguel et al. 2010; Machado et al. 2012; Coelho et al. 2013), and the means by which the exudates pass through this cuticular barrier remains unclear in some cases. We believe that micro-channels, which are seen as an electron-dense network in the cuticle layer, contribute to the flow of material to the outside without breaking the cuticle. Additionally, we observe that the polysaccharide material of the tangential cell wall protruded inside the cuticular layer forming pectin bands, which can act as a hydrophilic filler increasing the porosity of the cuticle to macromolecules (Wilkinson 1979; Jeffree 1996; Taiz and Zeiger 2013). This mechanism constitutes an apoplastic exit route for the exudate moving to the colleter surface. Our data confirm that the individual cuticle characteristics associated to the complex architecture of the outer cell wall have functional significance (Wilkinson 1979; Jeffree 1996), especially considering that the release of large amounts of exudates occurs through the entire colleter surface.

This study highlights the importance of combining conventional and cytochemical analyses in TEM (Fakan 2004) to investigate the relationships between subcellular structure and glands secretory function. The subcellular differences between colleters from forest and savanna Rubiaceae species, especially the population and topography of organelles, become more evident due to the combination of methods in TEM. Such differences reflect the predominance of lipid secretion in savanna species, which experience a more intense irradiance and, consequently, a drier and a hotter microclimate, in contrast with the prevalence of hydrophilic (mucilaginous-protein) secretions in forest species, which experience a shadier, cooler and moister microclimate.

The effect of climate on cell ultrastructure and the stimulation of several key enzymes that lead to the biogenesis of different substances as a reaction to different environmental factors (biotic and abiotic) is a widespread phenomenon in many plant tissues (see Roshchina and Roshchina 1993; Rios-Estepa et al. 2008; Ren et al. 2016). Collectively, environmental conditions (especially light and temperature) and the availability of non-mineral nutrients, macronutrients and micronutrients, greatly influence the amount of cells and their biochemical composition (lipids, proteins and carbohydrates) (see Roshchina and Roshchina 1993; Juneja et al. 2013). In general, all of these factors can affect photosynthesis (Ren et al. 2016), thus altering carbon fixation and the allocation of carbon into different types of macromolecules. On the other hand, the cell's macromolecular composition determines its usefulness in cell functioning (Juneja et al. 2013). We conjecture that differences in microclimate between forest and savanna vegetation, especially regarding radiation intensity, which is significantly higher in savanna vegetation (Tresmondi et al. 2015), may influence the colleters' cell metabolism, leading to changes in secretion composition. It is noticeable that all analysed colleters have cellular apparatus for the synthesis of lipids, polysaccharides and proteins. Considering that the eight analysed species belong to five tribes of Rubiaceae, it should be pointed out that some peculiarities observed here may also be characteristic of each species. Therefore, we argue that the subcellular plasticity in colleters' traits may represent a response to fine-scaled variation in microclimate conditions at modular level (in this case, vegetative apex), sensu Kroon et al. (2005). Further studies, under various experimental conditions, are needed to understand synergistic interactions between multiple environmental variables. 
Acknowledgements This article is part of the doctoral thesis of F. Tresmondi. We acknowledge the financial support of the National Council for Scientific and Technological Development (CNPq - financial support Proc. 473289/2010 and grants to the SR Machado Proc. 302657/ 2011-8) and the São Paulo Council for Research (FAPESP-financial support Thematic Project Proc. 2008/55434-7 and grants to the first author-Proc. 2011/02488-5). Thanks to the Electron Microscopy Centre (CME) IBB, UNESP and its technicians for assistance with sample preparations.

\section{References}

Angermüller S, Fahimi DH (1982) Imidazole-buffered osmium tetroxide: an excellent stain for visualization of lipids in transmission electron microscopy. Histochem J 14:823-825

Appezzato-da-Glória B, Estelita MEM (2000) Development, structure and distribution of colleters in Mandevilla illustris and M. velutina (Apocynaceae). Braz J Bot 23:113-120. doi:10.1590/S010084042000000200001

Benayoun J, Fahn A (1979) Intracellular transport and elimination of resin from epithelial duct-cells of Pinus halepensis. Ann Bot 43: 179-181. doi:10.1093/oxfordjournals.aob.a085622

Carvalho WA, Panoso LA, Moraes MH (1991) Levantamento semidetalhado dos solos da Fazenda experimental EdgardiaMunicípio de Botucatu. UNESP/FCA Boletim Científico, Botucatu, p 2

Coelho VPM, Leite JPV, Fietto LG, Ventrella MC (2013) Colleters in Bathysa cuspidate (Rubiaceae): development, ultrastructure and chemical composition of the secretion. Flora 208:579-590. doi:10. 1016/j.flora.2012.08.005

Coutinho LM (2002) O bioma do cerrado. In: Klein AL (ed) Eugen warming e o cerrado brasileiro: um século depois. Editora da Unesp, São Paulo, pp 77-91

Cunha AR, Martins D (2009) Classificação climática para os municípios de Botucatu e São Manuel-SP. Irriga 14:1-11

Davis AP, Govaerts R, Bridson DM, Ruhsam M, Moat J, Brummitt NA (2009) A global assessment of distribution, diversity, endemism, and taxonomic effort in the Rubiaceae. Ann Missouri Bot Gard 96:68 78. doi: $10.3417 / 2006205$

Delvaux B, Brahy V (2014) Mineral soils conditioned by a wet (Sub) tropical climate. FAO. Retrieved 30 September 2016

Déstro GFG, Campos S (2006) SIG-SPRING na caracterização do uso dos solos a partir de imagens do satélite CBERS. Energia 21:28-35

Empresa Brasileira de Pesquisa Agropecuária (EMBRAPA) (1999) Sistema brasileiro de classificação de solo. Centro Nacional de Pesquisa de Solos, Rio de Janeiro

Evert RF (2006) Esau's plant anatomy. John Wiley \& Sons, New Jersey

Fahn A (1979) Secretory tissues in plants. Academic Press, London

Fahn A (2000) Structure and function of secretory cells. Adv Bot Res 31: 37-75. doi:10.1016/S0065-2296(00)31006-0

Fakan S (2004) Ultrastructural cytochemical analyses of nuclear functional architecture. Eur J Histochem 48:5-14

Hall LJ, Flowers TJ, Roberts RM (1981) Plant cell structure and metabolism, 2nd edn. Longman Group Limited, New York

Horner HT, Lersten NR (1968) Development, structure and function of secretory trichomes in Psychotria bacteriophila (Rubiaceae). Am J Bot 55:1089-1099

Jeffree CE (1996) Structure and ontogeny of plant cuticles. In: Plant cuticles: an integrated functional approach. BIOS Scientific Publishers, Oxford, pp 33-82

Juneja A, Ceballos RM, Murthy GS (2013) Effects of environmental factors and nutrient availability on the biochemical composition of algae for biofuels production: a review. Energies 6:4607-4638. doi: 10.3390/en6094607

Kakani VG, Reddy KR, Zhao D, Sailaja K (2003) Field crop response to ultraviolet-B radiation: a review. Agric For Meteorol 120:191-218. doi:10.1016/j.agrformet.2003.08.015

Klein DE, Gomes VM, Silva-Neto SJ, Da Cunha M (2004) The structure of colleters in several species of Simira (Rubiaceae). Ann Bot 94: 733-740. doi:10.1093/aob/mch198

Kronestedt-Robards E, Robards A (1991) Exocytosis in gland cells. In: Hawea C, Coleman J, Evans D (eds) Endocytosis, exocytosis and vesicle traffic in plants. Cambridge University Press, Cambridge, pp 199-232

Kroon H, Huber H, Stuefer JF, van Groenedael JM (2005) A modular concept of phenotypic plasticity in plants. New Phytol 166:73-82. doi:10.1111/j.1469-8137.2004.01310.x

Lacchia APS, Tölke EEAD, Carmello-Guerreiro SM, Ascensão L, Demarco D (2016) Foliar colleters in Anacardiaceae: first report for the family. Botany 94:337-346. doi:10.1139/cjb-2015-0236

Lüttge U (1971) Structure and function of plant glands. Ann Rev Plant Physiol 22:23-44. doi:10.1146/annurev.pp.22.060171.000323

Machado SR, Barreiro DP, Rocha JF, Rodrigues TM (2012) Dendroid colleters on vegetative and reproductive apices in Alibertia sessilis (Rubiaceae) differ in ultrastructure and secretion. Flora 207:868 877. doi:10.1016/j.flora.2012.09.013

MacRae EK, Meetz GD (1970) Electron microscopy of the ammoniacal silver reaction for histones in the erythropoietic cells of the chick. J Cell Biol 45:235-245

Miguel EC, Gomes VM, Oliveira MA, Da Cunha M (2006) Colleters in Bathysa nicholsonii K. Schum. (Rubiaceae): ultrastructure, secretion protein composition, and antifungal activity. Plant Biol 8:715-722. doi:10.1055/s-2006-924174

Miguel EM, Klein DE, Oliveira MA, Da Cunha M (2010) Ultrastructure of secretory and senescence phase in colleters of Bathysa gymnocarpa and B. stipulata (Rubiaceae). Braz J Bot 33:425-436. doi:10.1590/S0100-84042010000300006

Nicotra AB, Atkin OK, Bonser SP et al (2010) Plant phenotypic plasticity in a changing climate. Trends in Plant Sci 15:684-692. doi:10.1016/ j.tplants.2010.09.008

Possobom CF, Guimarães E, Machado SR (2015) Structure and secretion mechanisms of floral glands in Diplopterys pubipetala (Malpighiaceae), a neotropical species. Flora 211:26-39. doi:10. 1016/j.flora.2015.01.002

Reinecke M, Walther C (1978) Aspects of turnover and biogenesis of synaptic vesicles at locust neuromuscular junctions as revealed by iodide-osmium tetroxide (ZIO) reacting with intravesicular shgroups. J Cell Biol 21:839-855

Ren B, Cui H, Camberato JJ, Dong S, Liu P, Zhao B, Zhang J (2016) Effects of shading on the photosynthetic characteristics and mesophyll cell ultrastructure of summer maize. Sci Nat 103:67. doi:10. 1007/s00114-016-1392-x

Reynolds ES (1963) The use of lead citrate at high $\mathrm{pH}$ as an electronopaque stain in electron microscopy. J Cell Biol 17:208-212

Rios-Estepa R, Turner GW, Lee JM, Croteau RB, Lange BM (2008) A systems biology approach identifies the biochemical mechanisms regulating monoterpenoid essential oil composition in peppermint. Proc Natl Acad Sci U S A 105:2818-2013. doi:10.1073/pnas. 0712314105

Roshchina VV, Roshchina VD (1993) Excretory function of higher plants. Springer-Verlag, Berlin

Sá-Haiad B, Silva CP, Paula RCV, Rocha JF, Machado SR (2015) Androecia in two Clusia species: development, structure and resin secretion. Plant Biol (Stuttg) 17:816-824. doi:10.1111/plb.12314

Sheue C-R, Chen YJ, Yang YP (2012) Stipules and colleters of the mangrove Rhizophoraceae: morphology, structure and comparative significance. Bot Stud 53:243-254 
Sheue C-R, Chesson P, Chen Y-J et al (2013) Comparative systematic study of colleters and stipules of Rhizophoraceae with implications for adaptation to challenging environments. Bot J Linn Soc 172: 449-464. doi:10.1111/boj.12058

Taiz L, Zeiger E (2013) Plant physiology, 5th edn. Sinauer Associates, Massachusetts

Thiéry JP (1967) Mise en evidence des polysaccharides sur coupes fines en microscopie eletronique. J Microsc 6:987-1017

Thomas V (1991) Structural, functional and phylogenetic aspects of the colleter. Ann Bot 68:287-305

Tresmondi F, Nogueira A, Guimarães E, Machado SR (2015) Morphology, secretion composition, and ecological aspects of stipular colleters in Rubiaceae species from tropical forest and savanna. Naturwissenschaften 102(11-12):73. doi:10.1007/s00114-015$1320-5$

Turner GW, Croteau R (2004) Organization of monoterpene biosynthesis in Mentha: Immunocytochemical localization of geranyl diphosphate synthase, limonene-6-hydroxylase, isopiperitenol dehydrogenase, and pulegone reductase. Plant Physiol 136:42154227. doi:10.1104/pp.104.050229

Turner G, Gershenzon J, Nielson EE, Froehlich JE, Croteau RB (1999) Limonene synthase, the enzyme responsible for monoterpene biosynthesis in peppermint, is localized in oil gland secretory cells. Plant Physiol 120:879-886

Vassilyev AE (2000) Quantitative ultrastructural data of secretory duct epithelial cells in Rhus Toxicodendron. Int J Plant Sci 161(4):615-630

Wiermann R (1981) Secondary plant products and cell and tissue differentiation. In: Stumpf PK, Conn EE (eds) The biochemistry of plants; a comprehensive treatise, vol 7. Academic Press, New York, pp 85116

Wilkinson HP (1979) The plant surface; the cuticle. In: Metcalfe CR, Chalk L (eds) Anatomy of the dicotyledons, vol 1. Clarendon Press, Oxford, pp 140-148 